\title{
Prenatal Development of Excitability in Cat Retinal Ganglion Cells: Action Potentials and Sodium Currents
}

\author{
I. Skaliora, ${ }^{1}$ R. P. Scobey, ${ }^{2}$ and L. M. Chalupa ${ }^{1}$ \\ Departments of 'Psychology and ${ }^{2}$ Neurology and the Neurobiology Graduate Group, University of California, Davis, \\ California 95616
}

\begin{abstract}
The development of precise retinofugal projections is dependent on activity-mediated events, but as yet nothing is known about the ontogeny of excitable membrane properties in retinal ganglion cells (RGCs). In order to begin to understand how functional maturity is attained in these neurons, whole-cell patch-clamp recordings were obtained from acutely dissociated RGCs of fetal and postnatal timed-pregnant cats. Current-clamp recordings revealed a pronounced developmental increase in the proportion of RGCs capable of generating action potentials. At embryonic day 30 (E30), 5 weeks before birth and during a time when RGCs are still being generated, electrical stimulation elicited spikes in only a third of the cells. None of these neurons were capable of multiple discharges in response to maintained depolarization. The proportion of spiking neurons increased during ontogeny, such that by E55 all RGCs could be induced to generate action potentials, with the majority manifesting repetitive spiking patterns. Application of tetrodotoxin abolished spike activity of all fetal RGCs, indicating that sodiummediated action potentials are present very early in development.
\end{abstract}

At the same time, voltage-clamp recordings revealed significant ontogenetic modifications in several key properties of the sodium currents $\left(I_{\mathrm{Na}}\right)$. These were $(1)$ a twofold increase in $\mathrm{Na}$ current densities; (2) a shift in the voltage dependence of both activation and steady state inactivation: with maturity, sodium currents activate at more negative potentials, while steady state inactivation of $I_{\mathrm{Na}}$ occurs at less negative potentials; and (3) a decrease in decay time constants of the $\mathrm{Na}$ current, at membrane potentials negative to $-15 \mathrm{mV}$. These developmental changes were largely restricted to the period of axon ingrowth (E30-E38), suggesting that maturation of $I_{\mathrm{Na}}$ is not the limiting factor for the onset of activity-dependent restructuring of retinofugal projections.

[Key words: retinal ganglion cells, whole-cell patch clamp, development, sodium conductance, action potentials, TTX]

There is good reason to believe that neuronal activity plays a key role in the establishment of specific connections in the developing visual system (for recent reviews, see Constantine-

\footnotetext{
Received June 16, 1992; accepted July 21, 1992.

We thank C. J. Snider for excellent technical assistance and L. C. Liets for participating in some of the experiments. We also thank Drs. Martin C. L. Wilson and David $\mathrm{W}$. Robinson for comments on the manuscript. This work was supported by NIH Grant EY-03991. I.S. was supported by a Regents fellowship from the University of California.

Correspondence should be addressed to Irini Skaliora, Psychology Department, University of California at Davis, Davis, CA 95616.

Copyright (C 1993 Society for Neuroscience 0270-6474/93/130313-11\$05.00/0
}

Paton et al., 1990; Kalil, 1990; Shatz, 1990). In particular, sodium-mediated action potentials are thought to underlie correlated activity patterns that stabilize certain synapses according to the Hebbian postulate. Support for this idea is provided by studies showing that application of tetrodotoxin (TTX), the voltage-gated sodium channel blocker, disrupts the normal refinements of early patterns of projections (Meyer, 1983; Dubin et al., 1986; Stryker and Harris, 1986). In the cat visual system, for instance, it has been demonstrated that infusion of TTX into the fetal brain prevents the formation of eye-specific domains in the dorsal LGN (Shatz and Stryker, 1988) and results in larger than normal retinogeniculate axon terminals (Sretavan et al., 1988).

The results of such studies imply that retinal ganglion cells can generate spikes early in ontogeny. Indeed, extracellular recordings from the intact embryonic retina have demonstrated that developing ganglion cells are capable of generating action potentials (Galli and Maffei, 1988; Meister et al., 1991). Discharges of neighboring cells in the embryonic rat retina have been shown to be positively correlated (Maffei and Galli-Resta, 1990), and periodic bursts of synchronous activity have been demonstrated in fetal cats and postnatal ferrets (Meister et al., 1991). Furthermore, electrical stimulation of the optic nerve can induce postsynaptic activity in some dorsal lateral geniculate neurons as early as embryonic day 39 (F.39; Shat7 and Kirkwood, 1984). As yet, however, nothing is known about the ontogeny of functional properties and the mechanisms underlying spike generation in developing retinal ganglion cells (RGCs).

Conventional electrophysiological experiments on very young mammalian neurons are difficult for a number of technical reasons, not the least of which is their small size. The use of dissociated cells, in conjunction with the whole-cell patch-clamp recording technique (Hamill et al., 1981; Lipton and Tauck, 1987), offers a powerful tool for assessing the electrophysiological properties of individual neurons. We have employed these techniques to study the development of excitability in ganglion cells of the fetal and postnatal cat retina. In this system, it is possible to relate functional development to structural refinements that occur during ontogeny since a great deal is already known about the anatomical and morphological maturation of these neurons and their projection patterns (for reviews, see Shatz and Sretavan, 1986; Chalupa and White, 1990).

In the present study, we addressed the following questions. When are fetal RGCs first capable of generating action potentials, and how does the excitability of these neurons change during development? Are the action potentials of fetal cells mediated by sodium? If so, what are the properties of sodium currents in developing RGCs? The findings are related to the pattern of ganglion cell ingrowth and the refinements that are 
known to occur during the establishment of mature retinal projection patterns.

Some of these findings have been published in abstract form (Skaliora et al., 1990, 1991).

\section{Materials and Methods}

Retrograde labeling of retinal ganglion cells. Dissociated retinal ganglion cells (RGCs) cannot be unequivocally identified based on morphological features. For this reason, RGCs were retrogradely labeled in vivo with rhodamine latex beads (RBs). All surgeries were carried out under sterile conditions in strict compliance with NIH guidelines. To backfill ganglion cells in prenatal animals, the fetal head was exposed through a small incision over the nonplacental portion of the uterus of a timedpregnant cat anesthetized with $2 \%$ halothane. RBs were injected bilaterally into the optic tract, dorsal lateral geniculate nucleus, and superior colliculus with a Hamilton syringe. Cranial landmarks were used to orient the placement of such injections. Postnatal animals were anesthetized with Telazol $(15.4 \mathrm{mg} / \mathrm{kg})$, and injections of RBs were made into the same brain regions using stereotaxic coordinates. After a $2 \mathrm{~d}$ survival period, the animals were deeply anesthetized with barbiturate and the eyes were removed and kept in a cold, oxygenated, buffered solution (solution A: Hanks' balanced salt solution, buffered with 15 mm HEPES, pH 7.3) until ready for dissection.

Retinal dissociation. Retinas were dissected from the sclera and pigment epithelium and enzymatically treated in a $\mathrm{Ca}^{2+} / \mathrm{Mg}^{2+}$-free Hanks' balanced salt solution containing cysteine $(1 \mathrm{~mm}$, Sigma $)$ and papain (25 $\mathrm{U} / \mathrm{ml}$, Worthington), at $30^{\circ} \mathrm{C}$ for $45-60$ min depending on the agc of the animal. The retinal fragments were subsequently rinsed three or four times in solution A, with DNase and antibiotics (gentamycin, 50 $\mu \mathrm{g} / \mathrm{ml}$ ) added to the final rinse and kept in rotating tubes at $5^{\circ} \mathrm{C}$ until aliquots were removed. Following brief trituration through a fire-polished Pasteur pipette, the cells were transferred to a recording chamber. Neurons from which recordings were obtained had translucent cell bodies with nongranular appearance and clear surfaces that often retained stumps of hroken processes (Fig. 1). Such cells remained viable for 20 $50 \mathrm{hr}$ after dissociation. There was a developmental change in the total membrane area as assessed from the cell capacitance measurements (mean $\pm \mathrm{SD})$, from $4.1 \pm 1.5 \mathrm{pF}(n=14)$ at E30 to $10.2 \pm 4 \mathrm{pF}(n=$ $23)$ at postnatal stages. Since the extent of processes on the dissociated cells did not vary appreciably with maturation (see Fig. 1), this change largely reflects an increase in somal size. Assuming a value of $1 \mu \mathrm{F} / \mathrm{cm}^{2}$ and a spherical shape, these values correspond to average cell body diameters of approximately $11.5 \mu \mathrm{m}$ at E30 and $18 \mu \mathrm{m}$ at postnatal ages.

Electrophysiological recordings. Isolated RGCs backfilled with RB were located in the recording chamber using an IM35 Zeiss epifluorescence microscope (400×; filters: BP 510-560, FT 580, LP 590) equipped with a mercury vapor lamp. Differential interference contrast optics were used to visualize the cell during the recording period. A Sutter Instruments P-87 puller was used to make patch pipettes from thickwalled $1.5-\mathrm{mm}-\mathrm{o}$.d. capillary tubing. Patch electrodes had resistances of 5-8 M $\Omega$ when filled with electrode solution (see below). Recordings were made with a patch-clamp amplifier (Axopatch 1-C; bandpass: 5 $\mathrm{kHz})$. Current-clamp and voltage-clamp data were digitized $(10,000$ or 1000 samples per trace respectively), displayed and stored for subsequent off-line analysis on an IBM AT computer. Software developed in our laboratory was used for data acquisition and analysis and the commercially available program SIGMA-PLOT was used for curve fitting and plotting.

Current-clamp recordings. To monitor the spike generation capability and firing patterns of developing RGCs, we used the perforated variation of the patch-clamp technique (Horn and Marty, 1988). With this method, electrical access to the cytoplasm is obtained as nystatin molecules are inserted into the patch membrane. This recording mode was preferred for current-clamp experiments because it minimizes dialysis of the cytoplasm. [It was not used for voltage-clamp recordings due to the much higher series resistance $\left(R_{s}\right)$ values, ranging from 20 to $50 \mathrm{M} \Omega$.] Recordings were typically obtained in a bath solution containing (in mм) $\mathrm{NaCl}, 140 ; \mathrm{CaCl}_{2}, 3 ; \mathrm{KCl}, 5 ; \mathrm{MgCl}_{2}, 1 ; \mathrm{HEPES}-\mathrm{NaOH}, 10$; and D-glucose, 5 (pH 7.3; osmolarity, 290-300 mOsm). The electrode solution contained (in mM) $\mathrm{KCl}, 140$; EGTA, 0.5; HEPES, 10; nystatin, $250 \mu \mathrm{g} / \mathrm{ml}$; and pluronic, $250 \mu \mathrm{g} / \mathrm{ml}$ to aid nystatin suspension. The osmolarity was adjusted to $280-290 \mathrm{mOsm}$ and the $\mathrm{pH}$ to 7.3 . To assess the cells' spike generation ability, steps of depolarizing current (typically varying from 1 to $60 \mathrm{pA}$ with a duration of 2-3 sec) were injected. For some cells, the effect of the membrane potential on spiking was examined by altering membrane voltage with injections of small, constant currents, before the stimulating currents were applied. For selected neurons, recordings were obtained in the presence of TTX (300 nM), preceded and followed by recordings in control solutions.

Voltage-clamp recordings. After formation of a high-resistance seal (gigaseal) between the recording electrode and the cell membrane, transient currents caused by pipette capacitance were compensated electronically before establishing the whole-cell configuration (Hamill et al., 1981). Recordings where the seal resistance was less than IG $\Omega$ were discarded. The cell capacitance was obtained from the calibrated ad justment of the amplifier and was used to calculate current densities. For isolation of the sodium currents $\left(I_{\mathrm{Na}_{\mathrm{a}}}\right)$, the extracellular solution contained (in mM) $\mathrm{NaCl}, 120 ; \mathrm{CsCl}, 5 ; \mathrm{CaCl}_{2}, 0.5 ; \mathrm{CoCl}_{2}, 2.5 ;$ tetraethylammonium (TEA)-Cl, 10; 4-aminopyridine, 10; HEPES-NaOH, 10; and D-glucose 10 (pH 7.3, osmolarity adjusted to $290-300 \mathrm{mOsm}$ ). The electrode solution contained (in $\mathrm{mM}$ ) $\mathrm{CsCl}, 120 ; \mathrm{NaCl}, 15 ; \mathrm{MgCl}_{2}, 1$; $\mathrm{CaCl}_{2}, 0 . \mathrm{I}$; TEA-acetate, 5; HEPES, 10; EGTA, 1.1; and ATP, 1 (pH 7.3; osmolarity, 280-290 mOsm). Typically, recordings were made at room temperature, around $24^{\circ} \mathrm{C}$

Control of membrane potential and a small voltage drop across the electrode were essential for the analysis of $\mathrm{Na}$ currents. After electronic compensation (usually $75-80 \%$ ), $R_{\text {s }}$ values ranged between 3 and $9 \mathrm{M} \Omega$. In large cells, as the membrane area and peak $\mathrm{Na}$ current increased, there was loss of voltage control, as indicated by a lack of graded inward current responses to voltage steps in the threshold range $(-50$ to -30 $\mathrm{mV})$, a delayed onset of the currents, and steep activation curves $(k<$ $3 \mathrm{mV}$ per $e$-fold change in activation). In order to obtain adequate voltage control during $I_{\mathrm{Na}}$ activation in these RGCs, the current amplitude was reduced, either by decreasing the extracellular $\mathrm{Na}$ concentration to $25-40 \mathrm{~mm}$ (substituted by tetramethylammonium or sucrose to maintain constant osmolarity), or by adding TTX $(30-75 \mathrm{~nm})$ to the bath solution. These modifications permitted an analysis of the $\mathrm{Na}$ currents throughout the developmental period studied. Such records, however, were not used for peak current amplitude or density measurements. In order to be included in the present study, the recordings had to fullfill two criteria: (1) an electrode voltage drop of less than 5 $\mathrm{mV}$ and (2) smoothly rising current-voltage $(I-V)$ relationships, giving rise to activation curves (fitted by Boltzmann equations) with a steepness factor $k>4$. In selected cells the adequacy of space clamp was assessed more directly, either by fitting the capacitance charging curves obtained in whole-cell recordings or by scaling currents reduced by different conditioning prepulses. In all cases that fullfilled the above two criteria, a single exponential provided an adequate fit and the scaled current traces overplotted, implying electrical homogeneity of the cell membrane. Overall, $73 \%$ (44 out of 60 ) of the RGCs obtained from fetal animals and $45 \%$ ( 23 out of 51 ) of the postnatal cells fullfilled the above requirements.

Analysis. Capacitative transients and leak currents were subtracted from the records by the use of scaled currents, obtained by averaging 10 hyperpolarizing pulses in which the potential was stepped from -75 to $-95 \mathrm{mV}$. The data were used to plot current-voltage $(I-V)$ relationships. To determine the voltage sensitivity of the Na conductance, activation curves were constructed by converting current values to conductances, using the equation

$$
I=g\left(V_{m}-E_{\mathrm{Na}}\right),
$$

where $I$ is the measured peak current generated at each command potential, corrected for the leak current; $V_{m}$ is the membrane voltage obtained from the command potential after corrections for the tip potential and the voltage drop across the electrode due to the series resistance; and $E_{\mathrm{Na}}$ is the sodium reversal potential, measured from the $I-V$ curve Activation and steady-state inactivation curves were fitted by minimizing the sum of squares, using Boltzmann equations. Decay time constants $\left(\tau_{h}\right)$ were calculated by linear regression as the inverses of the current slopes plotted on a semilogarithmic scale. Original current traces were fitted according to the formulas given in the Results (sIGMA-PLOT).

Since there was no evidence of multiple distributions for any of the parameters examined, the data are reported as means \pm SD throughout the article.

\section{Results}

Current-clamp recordings

All postnatal RGCs manifested spike activity in response to electrical stimulation. Small depolarizing currents $(2-10 \mathrm{pA})$ 

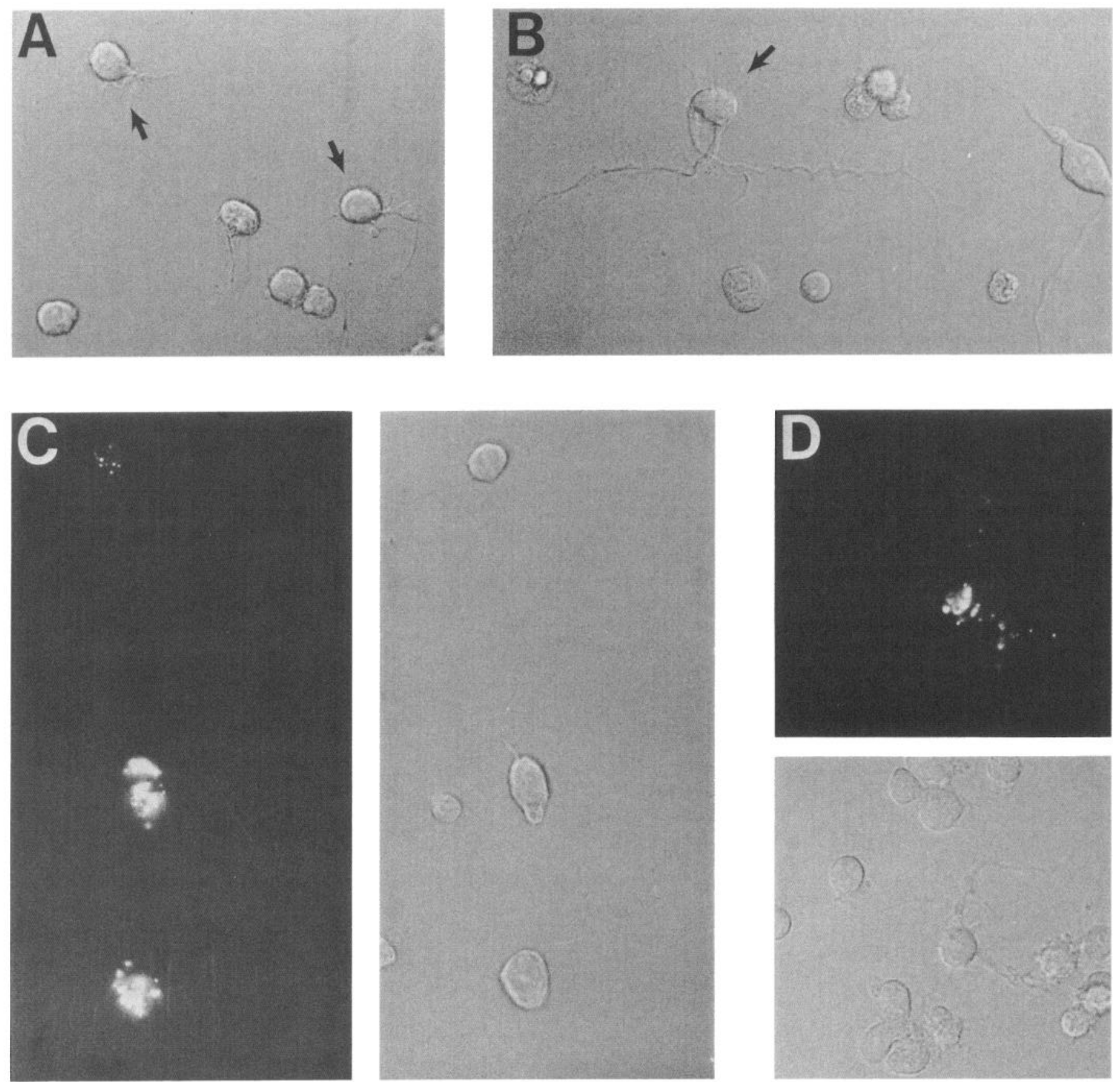

Figure 1. Photomicrographs of isolated RGCs. $A$ and B, Retinal cells dissociated from a retina of an E30 and an E35 animal, respectively. Arrows indicate RGCs (labeling not shown). Healthy neurons from which recordings were obtained had smooth surfaces, a three-dimensional appearance under Nomarski optics, and visible nuclei when focused accordingly. Typically, dissociated cells retained short processes on their somata $(A)$. In rare cases, however, as in the neuron in $B$, extensive processes were preserved. Recordings from such cells were usually not considered for kinetic analysis due to space-clamp problems. $C$, Three RGCs from an E35 retina. The cells were labeled by injections of RBs as shown in the fluorescent picture (left). Processes in these neurons are out of the plane of focus. D, Labeled neuron from an E38 retina. Often, the fluorescent tracer (top) was apparent in the processes of the cell.

were sufficient to evoke action potentials. Some cells fired in a sustained manner over a wide range of current intensities (2$45 \mathrm{pA})$. In these cases, spike activity lasted for the duration of the stimulus and the amplitude of action potentials remained fairly constant (Fig. 2A). With increasing stimulus intensities there was an increase in response frequency. Other cells responded in a transient manner at all stimulus intensities. Such cells generated a limited number of spikes of decreasing am- plitudes, followed by a stabilization of the membrane potential at a fairly depolarized level that was maintained until the stimulus was terminated (Fig. $2 B$ ). In some cases, only a single spike was generated. For any given cell, the response pattern was invariant as demonstrated by repeated recordings. There was no correlation between spiking properties and soma size, extent of processes present, or the resting membrane potential. RGCs manifesting sustained firing patterns had an average resting po- 

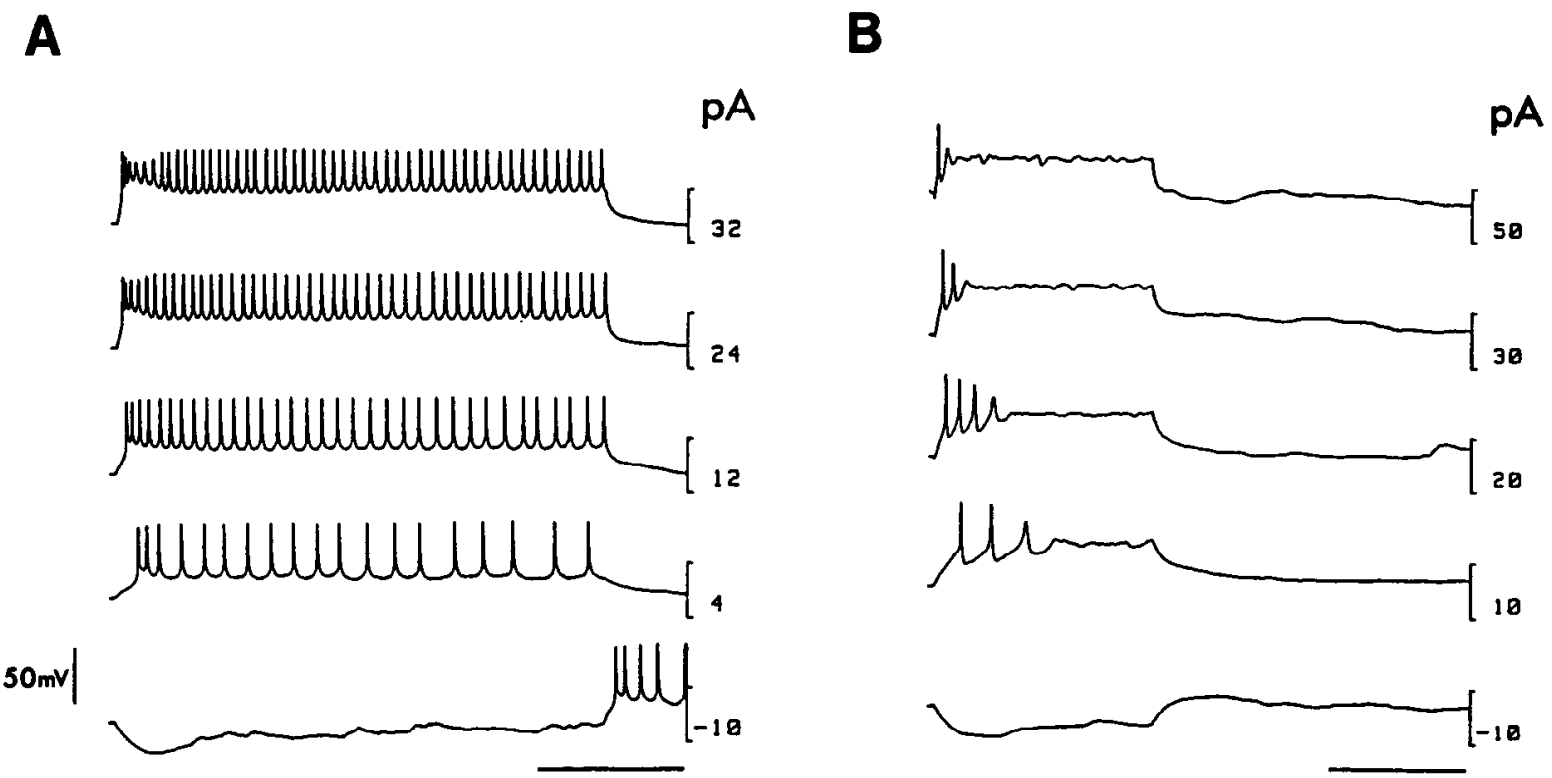

Figure 2. Responses to current injections in postnatal cells: sustained $(A)$ and transient $(B)$ spiking patterns. Each trace illustrates the cell's response to a current pulse injected through the patch electrode. The numbers on the right of each trace represent the current intensity in pA, the negative sign defining a hyperpolarizing current. Note that for the sustained pattern the frequency of the response increases with increasing stimulus intensities. As in most cells that showed this response, action potentials werc of nearly constant amplitude and duration for the length of the current injection. In contrast, for the cells manifesting transient firing patterns, action potentials tend to become longer and smaller during the response. In some cases, only a single action potential was elicited. Time calibration, $500 \mathrm{msec}$.

tential of $-59 \pm 14 \mathrm{mV}$ and an average cell capacitance of 17 $\pm 2 \mathrm{pF}(n=13)$, while for RGCs that fired transiently these values were $-65 \pm 11$ and $17 \pm 3 \mathrm{pF}(n=11)$, respectively (mean $\pm \mathrm{SD}$ ). Sustained and transient firing patterns in response to electrical stimulation have also been observed in recordings from acutely dissociated rat (Barres et al., 1988) and tiger salamander RGCs, as well as in salamander retinal whole-mounts (Mobbs et al., 1992).

Both response patterns were also evident in recordings of RGCs obtained from fetal animals as illustrated for the two neurons shown in Figure 3 . In embryonic cells, the average resting potential was $-50 \pm 13 \mathrm{mV}(n=47)$. In any given neuron, the same response pattern was obtained over a wide range of stimulus intensities and repeated recordings.

There were three clear changes in spike generation over the developmental period we studied. First, there was a dramatic increase in the proportion of spiking RGCs (Fig. 4A). At E30, the youngest age examined, action potentials could be evoked in only $33 \%$ of our sample $(n=15)$, whereas by E37 the majority of RGCs (75\%) manifested spike activity in response to depolarizing currents $(n=8)$. This percentage continued to increase such that by E55 all RGCs could generate spikes when electrically stimulated. Second, in cases where they did spike, these youngest neurons required much larger current steps ( $40 \mathrm{pA})$ compared with postnatal cells, and action potentials tended to be of smaller amplitude and longer duration than those seen at older ages (data not shown). By E45, the characteristics of individual action potentials were not appreciably different from those scen in postnatal cells. Third, there was a progressive increase in the proportion of cells that manifested repetitive firing. At E30 only single spikes could be elicited. Repetitive firing was first seen around E35-E37, when about $15 \%$ of the cells $(n=27)$ generated such responses. By comparison, the majority of postnatal cells $(71 \%)$ responded in a repetitive manner $(n=21)$. These results are summarized in Figure $4 B$, where dark, light, and hatched histograms represent nonspiking cells, single-spiking cells, and cells that manifested repetitive firing, respectively.

\section{Effects of TTX application on spike generation}

To detcrminc whether action potentials in fetal RGCs are sodium mediated, we examined the effects of the voltage-gated $\mathrm{Na}$ channel blocker TTX on spike generation. Application of TTX $(n=4)$ completely abolished the spike activity riding on the membrane depolarization (Fig. 5), indicating that action potentials in RGCs are mediated by sodium. In view of these findings, we sought to characterize the isolated $I_{\mathrm{Na}}$ during development, specifically, (1) the amplitude and density of the peak current, (2) the voltage dependence of activation and steadystate inactivation, and (3) the kinetics of $I_{\mathrm{Na}}$ decay.

\section{Identification and amplitude of $\mathbf{I}_{N a}$}

Voltage-dependent sodium currents were isolated by pharmacological channel blockers and ion substitution and were identified by reversible blocking with TTX and by the influence of external $\mathrm{Na}$ concentration on current amplitude. Figure 6 illustrates representative current traces from RGCs, obtaincd from animals at three different fetal ages (E30, E35, E38). These currents were evoked from a holding potential of $-90 \mathrm{mV}$ to voltages between -45 and $+55 \mathrm{mV}$. Maximum currents, obtained at potentials between -12 and $-5 \mathrm{mV}$, increased with age. For the entire sample of cells, the mean maximum amplitudes increased, from $230 \pm 94 \mathrm{pA}(n=13)$ at $\mathrm{E} 30$ to $1530 \pm 325 \mathrm{pA}$ $(n-14)$ in RGCs obtained from postnatal cats (Fig. $7 A$ ). There were no significant differences in the maximum $I_{\mathrm{Na}}$ among postnatal cells (P5-P16), so these values have been grouped together as $\mathrm{P} 10$, in this and all subsequent figures.

To take into account the increase in cell size that occurs with maturation (see Materials and Methods), the maximum $I_{\mathrm{Na}}$ was normalized to the cell capacitance. As may be seen in Figure 


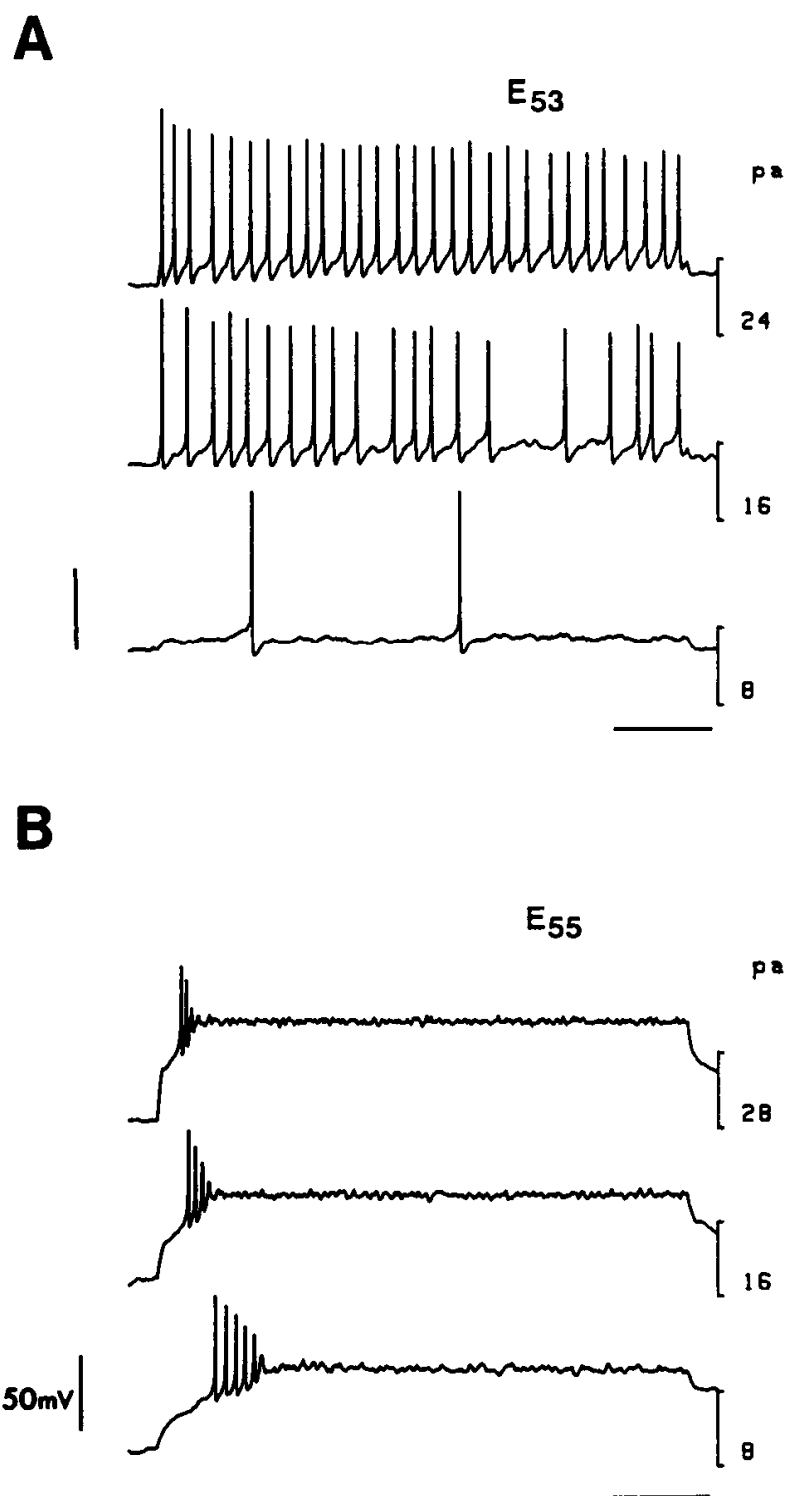

Figure 3. Spiking patterns in fetal RGCs. $A$, Response of an E53 neuron to injections of depolarizing current. Stimulus intensity is shown to the right of each trace (in pA). A sustained firing pattern is seen, similar to the one described for the postnatal cell in Figure $2 A$. $B$, Response of an E55 neuron to analogous stimulus parameters. This cell responded in a transient manner at all current intensities, like the postnatal neuron of Figure $2 B$. Time calibration, $500 \mathrm{msec}$.

$7 B$, there was a twofold increase in $I_{\mathrm{Na}}$ density. Interestingly, this increase is largely restricted to the period between E30 and E38, indicating that after E38 the increase in current amplitude is simply due to an increase in cell size.

\section{$\mathrm{I}_{N a}$ activation and steady-state inactivation}

Figure $8 A$ shows $I-V$ relations for two RGCs, obtained from an E30 (triangles) and a P16 (circles) animal. In the fetal cell, sodium currents activated at $-38 \mathrm{mV}$ and reached a peak at -9 $\mathrm{mV}$. For the postnatal neuron, $I_{\mathrm{Na}}$ activated at $-50 \mathrm{mV}$ and the peak was reached at $-15 \mathrm{mV}$. The difference in reversal potential is due to the reduced extracellular $\mathrm{Na}$ concentration required to obtain adequate space clamp of $I_{\mathrm{Na}}$ in postnatal cells. Reversal potentials were near the calculated sodium equilibrium potential (see figure caption). Figure $8 B$ shows the $\mathrm{Na}$ activation
A

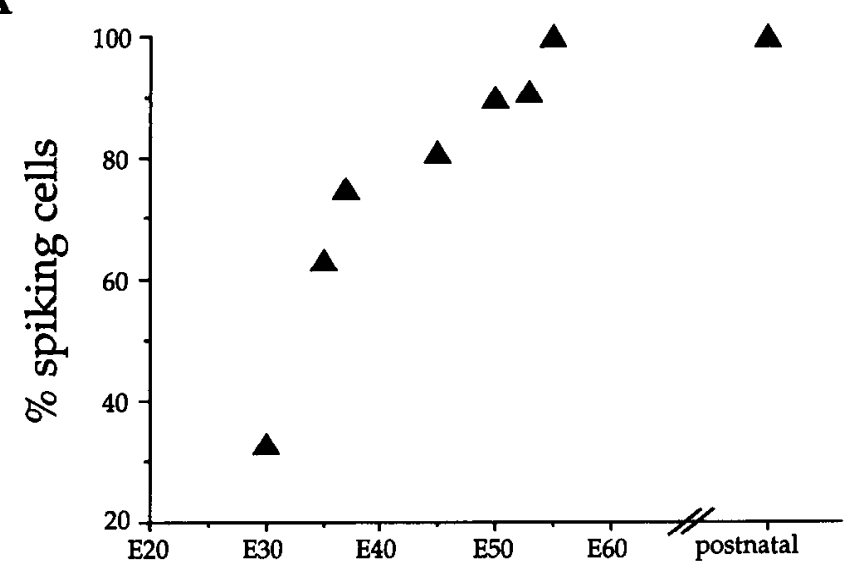

$\mathbf{B}$

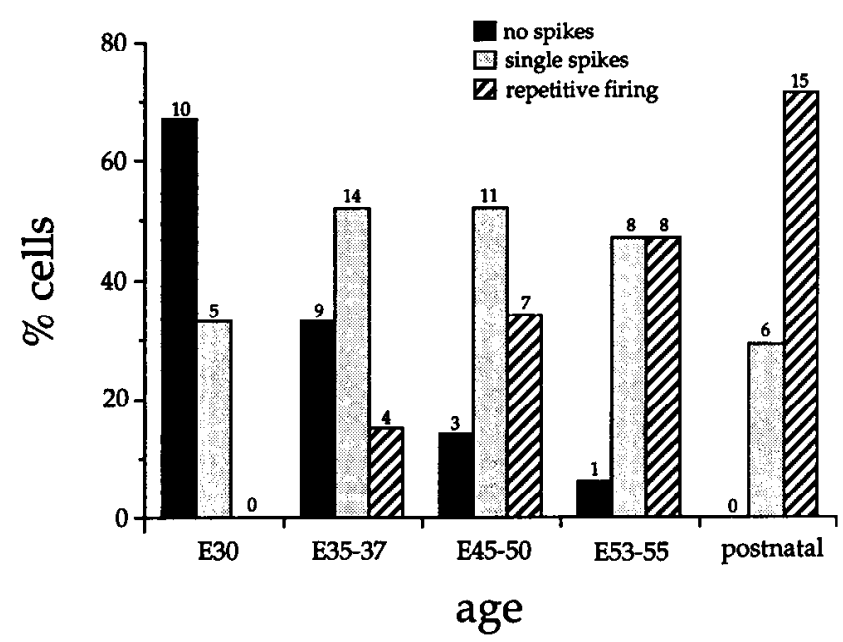

Figure 4. Development of excitability in fetal and postnatal RGCs. $A$, Percentage of cells that were capable of generating action potentials in response to electrical stimulation as a function of age. There were no differences among postnatal neurons of different ages, so these data are grouped together. $B$, Cells are categorized based on their spiking properties. Dark, light, and hatched histograms represent nonspiking neurons, those that generated only one spike in response to maintained stimulation, and those that manifested repetitive (sustained or transient) firing, respectively. The percentage of nonspiking neurons decreases dramatically during embryonic development; cells that manifest repetitive firing first appear around E35, and their percentage gradually increases with fetal development. The number of cells in each group is noted over the bars in the histogram.

curves for the same neurons as in Figure $8 A$, fitted with the following equation:

$$
g=g_{\max } /\left(1+\exp \left(\left(\mathrm{Va}_{1 / 2}-V\right) / k\right)\right)
$$

where $\mathrm{Va}_{1 / 2}$ is the voltage at half-maximum activation, $k$ is the steepness factor of the curve, and $g$ is calculated from the equation in Materials and Methods. The data points are represented by symbols, whereas the computer-derived fit of the data is represented by the lines. The midpoint of the activation curve, that is, the voltage at which $50 \%$ of the sodium currents become activated, was used to compare the voltage sensitivity of the $\mathrm{Na}$ currents in RGCs obtained at various stages of development. This is illustrated in Figure 9, where $\mathrm{Va}_{y_{2}}$ is plotted as a function of age. Between E30 and P10, there is a $7 \mathrm{mV}$ shift in the activation curve toward more negative values. The change in 

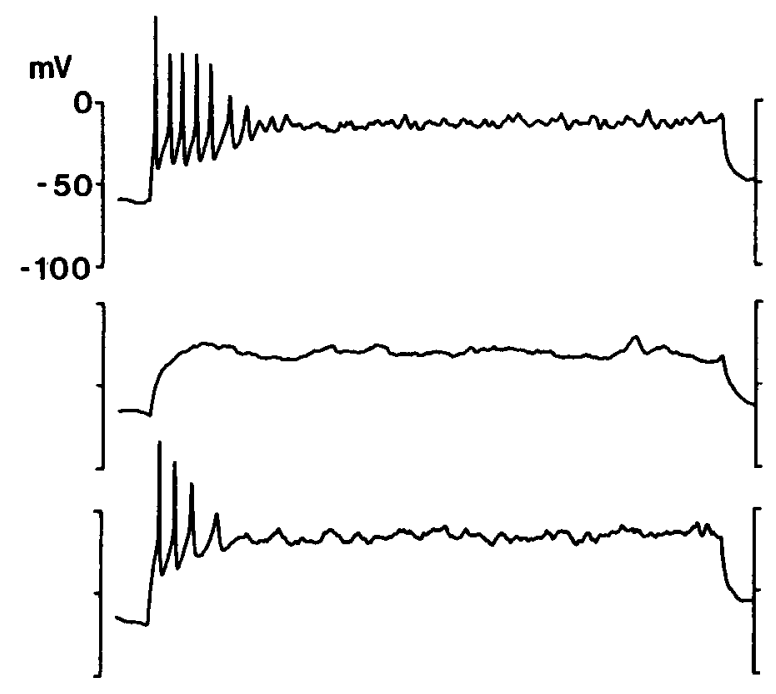

Figure 5. Effects of TTX application on spike generation. Currentclamp records were obtained from an E38 RGC. The top trace illustrates the cell's response to $20 \mathrm{pA}$ depolarizing current. The middle trace is the response of the same neuron to the same stimulus, but with $300 \mathrm{~nm}$ TTX included in the bath solution. The membrane is depolarized by the injected current, but the spikes riding on the depolarization have disappeared. After TTX is washed out of the bath (bottom trace), the spike activity is recovered. Time calibration, $500 \mathrm{msec}$.

the average $\mathrm{Va}_{1 / 3}$ between $\mathrm{E} 30$, E35, and $\mathrm{E} 38$ is statistically significant in every case $(p<0.05)$. After E38, however, this value remains relatively constant.

The steady-state inactivation experiment was performed by varying the amplitude of a $200 \mathrm{msec}$ prepulse from -90 to -20 $\mathrm{mV}$, at 10 or $5 \mathrm{mV}$ steps. The $10 \mathrm{msec}$ test depolarization was always to $-10 \mathrm{mV}$. Figure 10 illustrates representative current traces obtained with this protocol for an E38 cell. $I-V$ graphs were constructed by plotting the peak currents as a function of the prepulse potential (Fig. $11 \mathrm{~A}$ ), and a steady-state inactivation curve was constructed and fitted with a Boltzmann equation (Fig. $11 B$ ). As indicated in Figure 11 (dotted lines), at $-50 \mathrm{mV}$ half of the Na current in this neuron was inactivated. Figure 9 shows the midpoint of inactivation $\left(\mathrm{Vh}_{1 / 2}\right)$ as a function of age for the entire sample of cells. There is a significant $(p<0.01)$ shift toward more positive potentials with development; $\mathrm{Vh}_{1 / 2}$ increases from $-61 \pm 3 \mathrm{mV}(n=25)$ at $\mathrm{E} 30$, to $-50 \pm 3.5 \mathrm{mV}$ $(n=23)$ in postnatal cells (mean \pm SD).

\section{Kinetics of $\mathrm{I}_{N a}$ decay $\left(\tau_{\mathrm{h}}\right)$}

To examine the kinetics of the $I_{\mathrm{Na}}$ decay, data were plotted as the logarithm of $I_{\mathrm{Na}}$ versus time. The slope of the log current was determined by fitting a regression line through the data, beginning at 1.5 times the time to peak. The values of the current

Figure 6. Voltagc-gated sodium currents in fetal RGCs. In all cases, the holding potential was $-90 \mathrm{mV}$ and whole-cell $\mathrm{Na}$ currents were measured during $25 \mathrm{msec}$ voltage steps to potentials between -50 and $+5 \mathrm{mV}$. The bath solution included $2.5 \mathrm{mM} \mathrm{CoCl}_{2}$ to block calcium currents, and in the recording pipette $\mathrm{K}^{+}$was replaced by $\mathrm{Cs}^{+}$and TEA to block outward currents. Traces are voltage-clamp recordings from an E30 $(A)$, E35 $(B)$, and E38 $(C)$ neuron after correction for series resistance, leak current, and capacitative transient, as described in Materials and Methods. Note the difference in scale, indicating the increase in current amplitude with age. In all cases, the bath solution contained $120 \mathrm{~mm} \mathrm{NaCl}$.
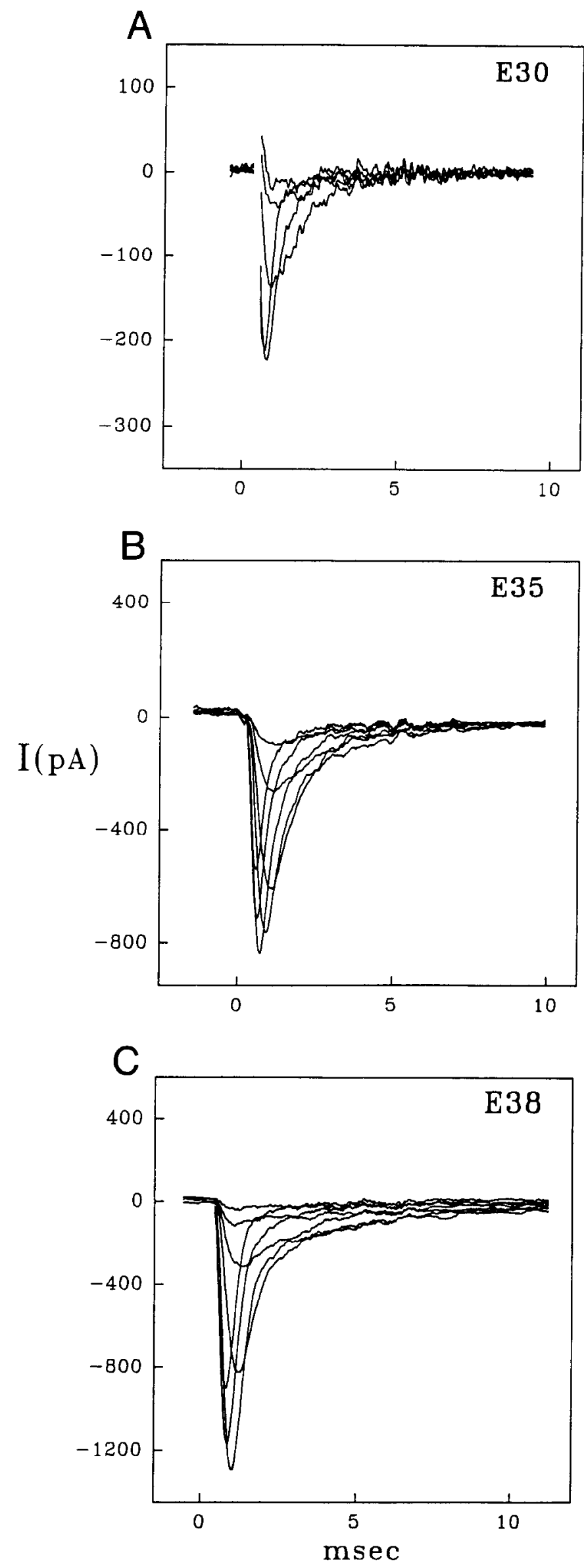
A
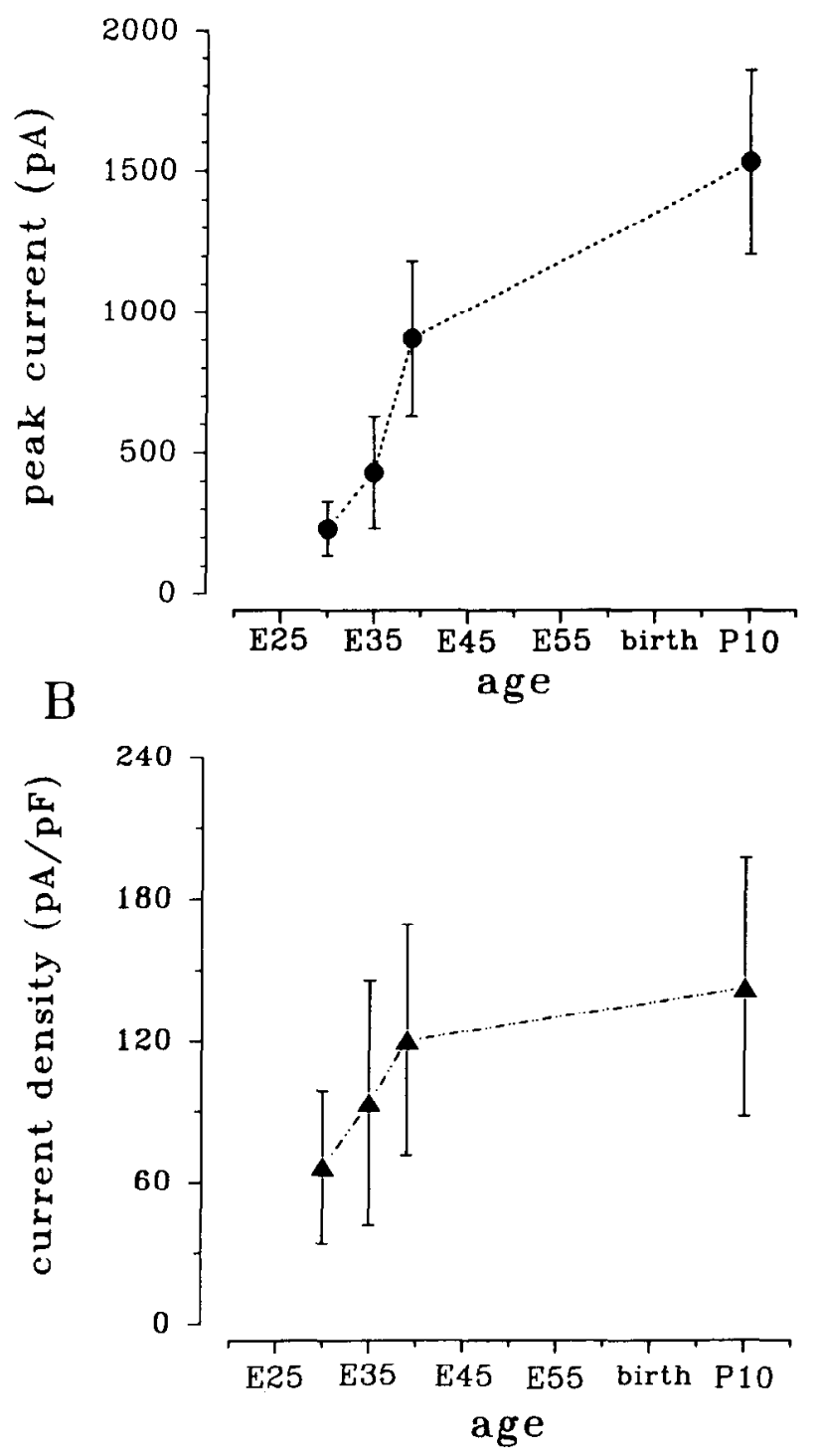

Figure 7. Sodium currents in RGCs as a function of age. Peak sodium current amplitudes $(A)$ and densities $(B)$ plotted versus age. Symbols represent the mean values for all cells at each age, and error bars, the SD. An eightfold increase in current amplitudes was observed. Mean values \pm SD for the different ages were as follows: $230 \pm 94 \mathrm{pA}$ at E30, $429 \pm 196 \mathrm{pA}$ at E35, $903 \pm 278 \mathrm{pA}$ at E38, $1530 \pm 325 \mathrm{pA}$ postnatally. When the increase in cell size was taken into consideration, current densities were found to increase by twofold, and most of the change occurred over the early developmental period (E30-E38). Mean values $\pm \mathrm{SD}$ were as follows (in pA/pF): $66 \pm 32(n=10)$ at $\mathrm{E} 30,94 \pm 52$ $(n=16)$ at E35, $120 \perp 49(n=10)$ at E38, and $143 \pm 54(n-12)$ postnatally. In all recordings, the bath solution contained $120 \mathrm{mM} \mathrm{NaCl}$.

slopes were used to calculate the decay time constants $\left(\tau_{h}\right)$. The accuracy of $\tau_{h}$ was subscquently verificd in sclected records, by fitting the following equation to the data:

$$
I_{\mathrm{Na}}=G_{\mathrm{Na}}\left(V_{m}-E_{\mathrm{Na}}\right) \exp \left(-t / \tau_{h}\right),
$$

where $G_{\mathrm{Na}}$ is the Na conductance at the peak of $I_{\mathrm{Na}}$ (as illustrated in Fig. 12A) and $\tau_{h}$ is the time constant of inactivation. The decay of the $\mathrm{Na}$ current at different voltage steps is illustrated in Figure 12 $A$, for an E30 and a P16 RGC. A single exponential decay (smooth lines) provided an adequate fit for the recorded
A
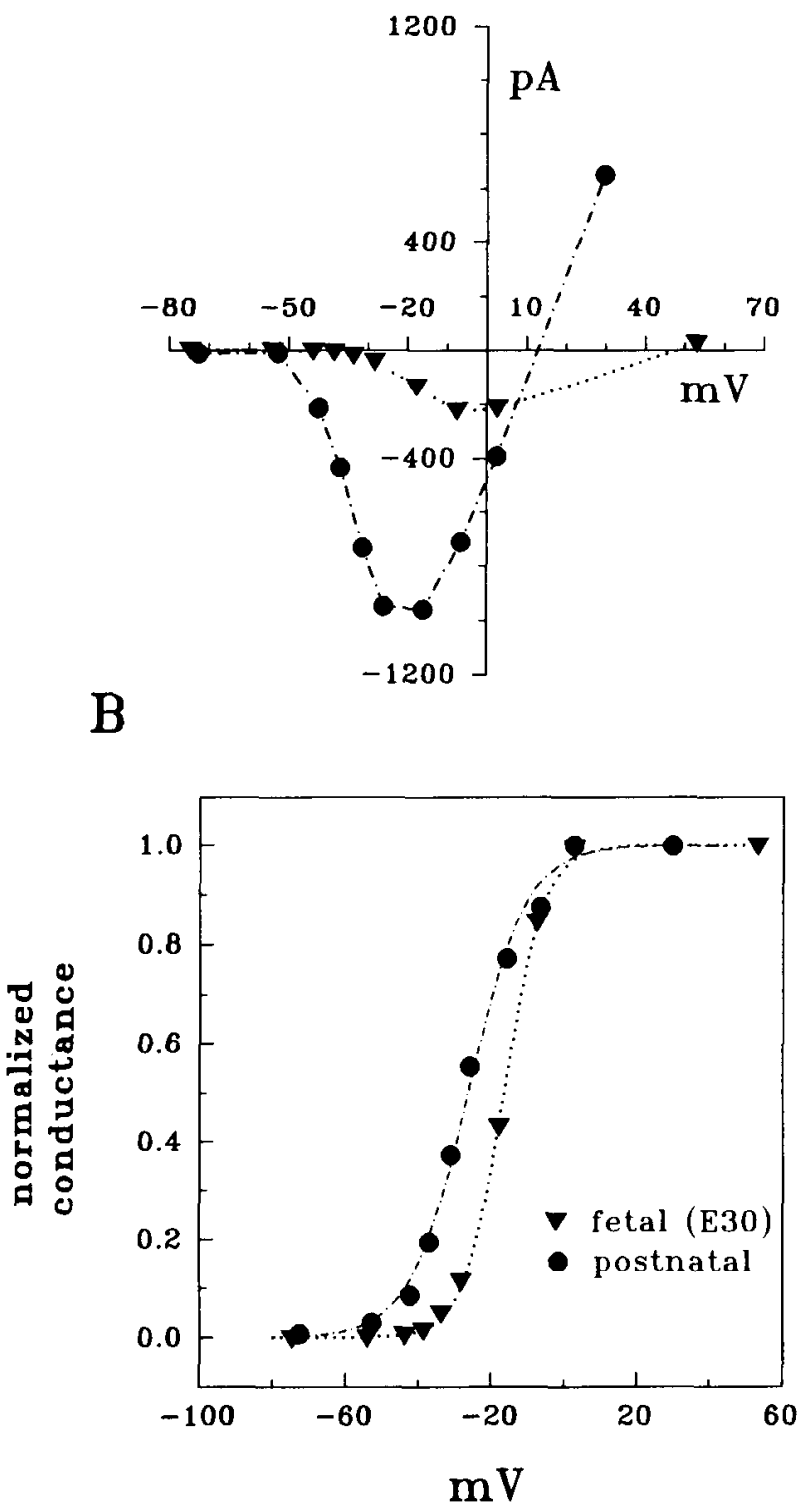

Figure 8. Activation of sodium currents. $A$, Current-voltage relationship of $I_{\mathrm{Na}}$ in an E30 and a postnatal (P16) RGC. Whole-cell Na currents were elicited from a holding potential of $-90 \mathrm{mV}$. Peak currents are plotted as a function of the voltage step, after the appropriate corrections were applied. For the postnatal cell the bath solution contained $25 \mathrm{~mm}$ $\mathrm{NaCl}$ to reducc $\mathrm{Na}$ current amplitude (substituted by tetramethylammonium to maintain osmolarity). $B$, Activation curve of the Na currents for the same neurons. Peak current values were converted to conductances from the equation $I=g\left(V_{c}^{r}-E_{\mathrm{Na}}\right)$, where $V_{c}$ is the command potential corrected for series resistance. $E_{\mathrm{Na}}$ is $48 \mathrm{mV}$ for the fetal and $13 \mathrm{mV}$ for the postnatal RGC from the $I-V$ curves (the discrepancy being due to different external $\mathrm{Na}$ concentrations). Conductance values were normalized to 1 , and a Boltzmann equation was fit to the data. Symbols represent the data points (triangles for the E30 and circles for the postnatal neuron), and the lines are the fitted curves. The midpoint of the activation curve $\left(\mathrm{Va}_{1 / 2}\right)$ is $-17.4 \mathrm{mV}$ for the fetal and $-24.1 \mathrm{mV}$ for the postnatal RGC

currents. Moreover, when large numbers of current traces were averaged $(60-80)$, the variance was found to be proportional to the mean current amplitude (data not shown), indicating that only one type of sodium channel is present on RGCs.

Figure $12 B$ shows mean decay time constants of the $I_{\mathrm{Na}}$ mea- 


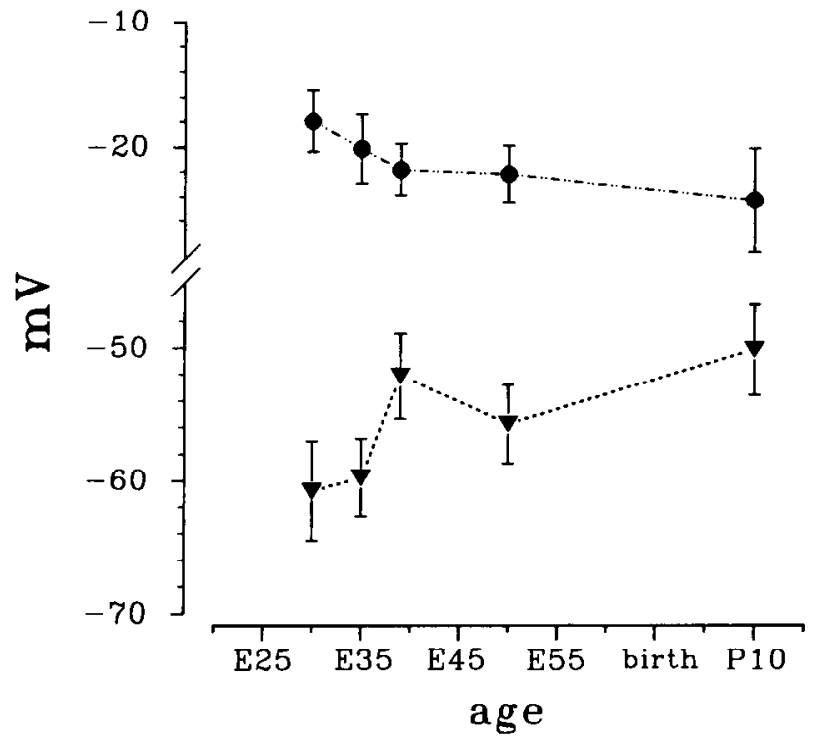

Figure 9. Voltage dependence of activation and steady-state inactivation in developing $\mathrm{RGCs}$. The midpoints of the activation ( $\mathrm{Va}_{1 / 2}$; circles) and inactivation ( $\mathrm{Vh}_{1,}$; triangles) curves are plotted as a function of age. With maturation, the average $\mathrm{Va}_{1 / 2}$ shifts toward more negative potentials, mean values \pm SD for the different ages being as follows (in $\mathrm{mV}):-17.9 \pm 2.47(n=11)$ at $\mathrm{E} 30,-20.1 \pm 2.8(n=17)$ at $\mathrm{E} 35$, $-22.97 \pm 2.5(n=10)$ at $\mathrm{E} 38,-22.2 \pm 2.3$ at $\mathrm{E} 50(n=8)$, and -24.3 $\pm 4.1(n=24)$ at postnatal ages. At the same time, $\mathrm{Vh}_{1 / 2}$ shifts to more positive potentials: $-60.8 \pm 3.7 \mathrm{mV}(n=10)$ at $\mathrm{E} 30,-59.8 \pm 2.9 \mathrm{mV}$ $(n=17)$ at $\mathrm{E} 35,-52.1 \pm 3.2 \mathrm{mV}(n=11)$ at E38, $-55.7 \pm 2.9 \mathrm{mV}$ $(n=8)$ at E50, and $-50.1 \pm 3.4 \mathrm{mV}(n=18)$ postnatally. It can be seen that both activation and steady-state inactivation parameters have shifted toward each other.

sured at different command potentials for RGCs obtained from early fetal (E30 and E35) and postnatal animals. Kinetics of the sodium current became faster at more positive potentials, and at voltages positive to $-15 \mathrm{mV}$, the curves were essentially identical for RGCs of different ages. However, at more negative potentials, younger cells manifested significantly larger time constants $(p<0.01)$. For instance, at $-25 \mathrm{mV}$ the mean values

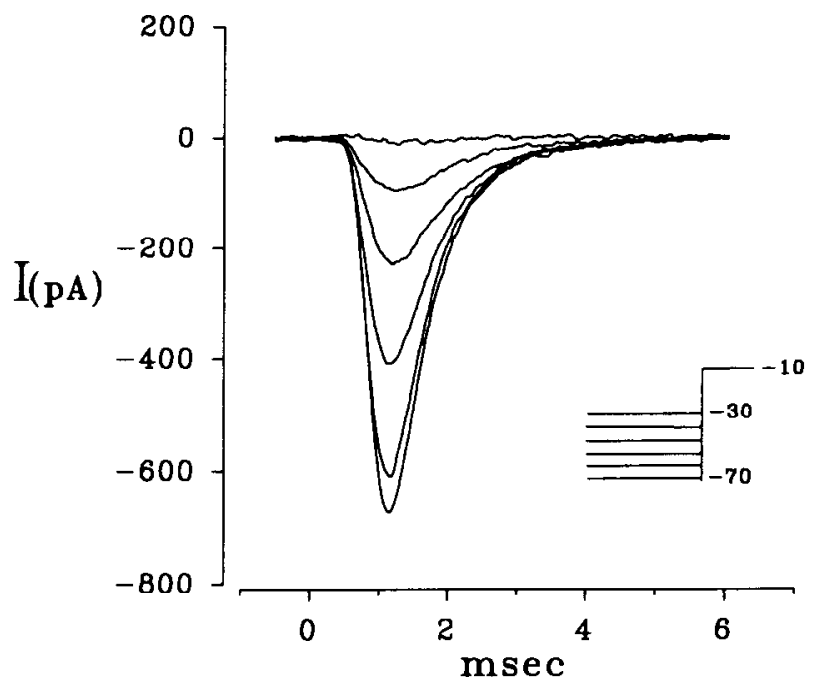

Figure 10. Steady-state inactivation of Na currents. Currents were obtained from an E38 RGC by step depolarizations to a test potential of $-10 \mathrm{mV}$, after a $200 \mathrm{msec}$ conditioning prepulse, at voltages ranging from -90 to $-20 \mathrm{mV}$ (protocol shown in the inset).
A

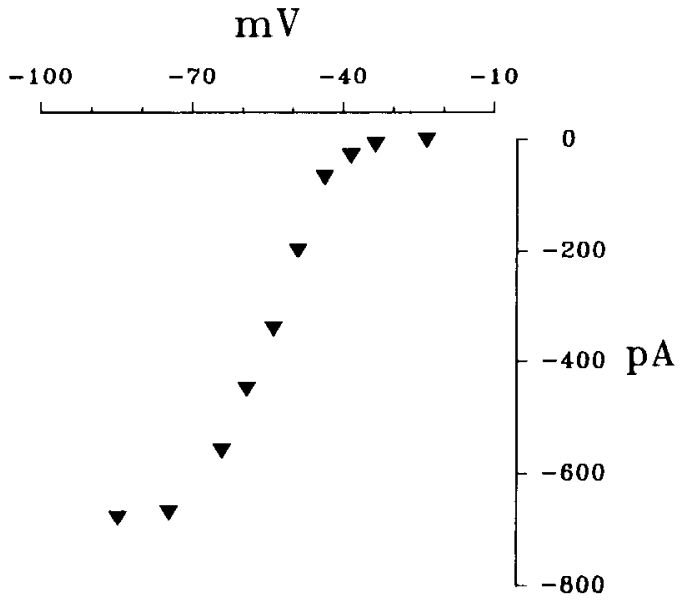

B

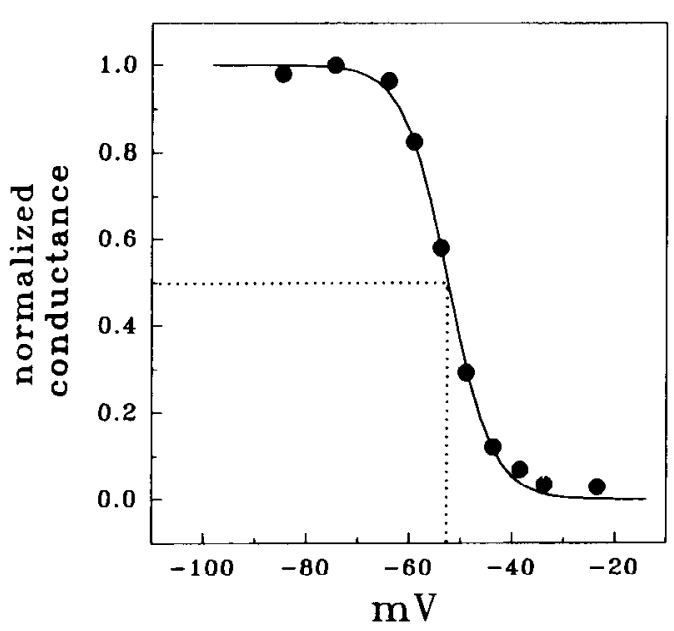

Figure 11. Voltage dependence of steady-state inactivation. $A, I-V$ curve illustrating the sodium current generated at the test potential $(-10$ $\mathrm{mV}$ ), as a function of conditioning prepulse potentials, from the same E38 neuron of Figure 10 . In $B$ currents are converted to conductances as described previously, conductance values are normalized to 1 , and a Boltzmann equation (solid line) is fitted to the data points (symbols). For this neuron the midpoint of the inactivation curve is $-52.7 \mathrm{mV}$, as indicated by the dotted lines.

for the fetal and postnatal cells were $1.86 \pm 0.83 \mathrm{msec}(n=19)$ and $0.94 \pm 0.37 \mathrm{msec}(n=10)$, respectively. As might be expected from the developmental change noted in the voltage dependence of the activation, the $\tau_{h}$ curve of more mature cells was also shifted to the left, and sodium currents at the most negative potentials were not present in the younger neurons.

\section{Discussion}

In this study, we have begun to address the functional development of retinal ganglion cells in fetal and postnatal cats. To our knowledge, this is the first study to examine membrane properties of developing RGCs in a system that has served as a model for the role of activity in the establishment of specific connections in the mammalian brain. We show that during the early period of ontogeny there is a pronounced increase in excitability of RGCs as well as significant changes in Na current properties.

The earliest recordings were obtained at E30, which is during the period of RGC generation (Kliot and Shatz, 1982; Walsh et 


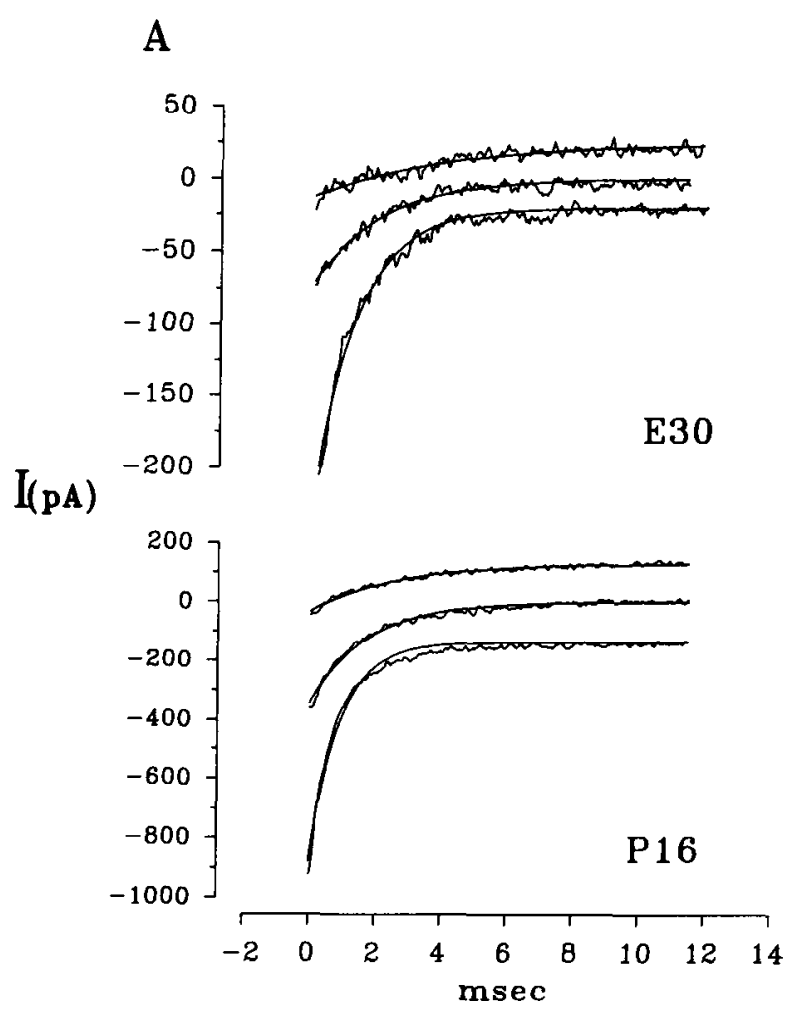

B

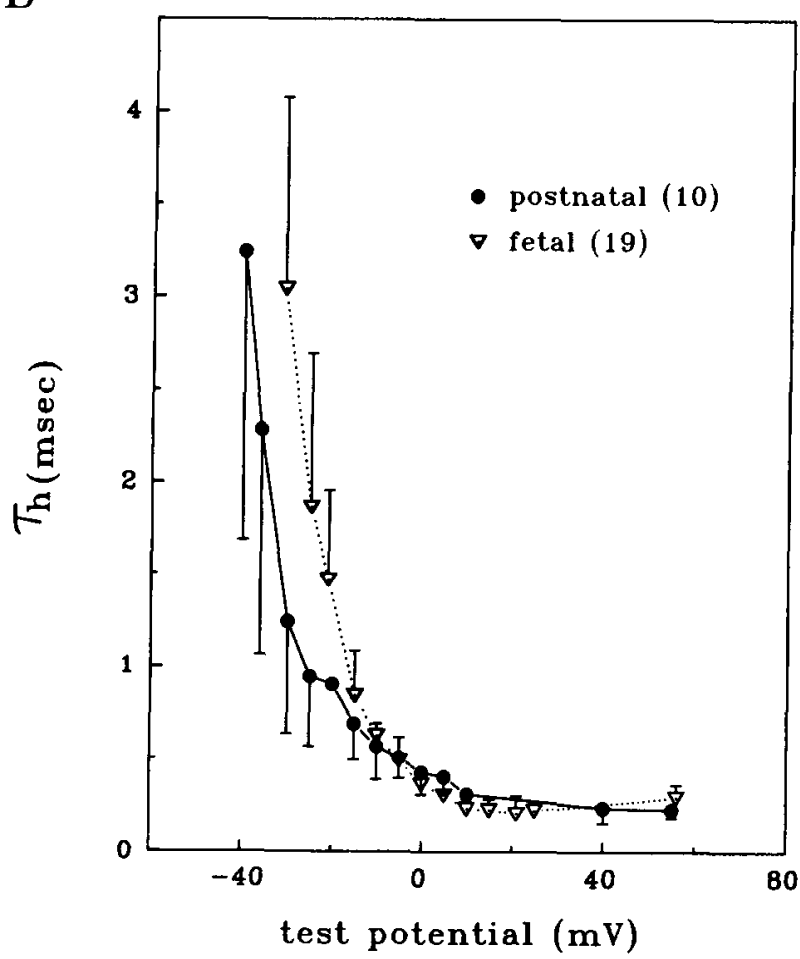

Figure 12. Kinetics of $I_{\mathrm{Na}}$ decay. A, Single exponential curves (smooth lines) were fitted to three representative current traces from two RGCs obtained from an E30 (top) and a postnatal (bottom) animal. Only the current decay is shown, that is, the part of the record beginning at the peak. For clarity, the top and bottom traces in each graph are displaced away from the middle trace (by $15 \mathrm{pA}$ for the fetal and $70 \mathrm{pA}$ for the

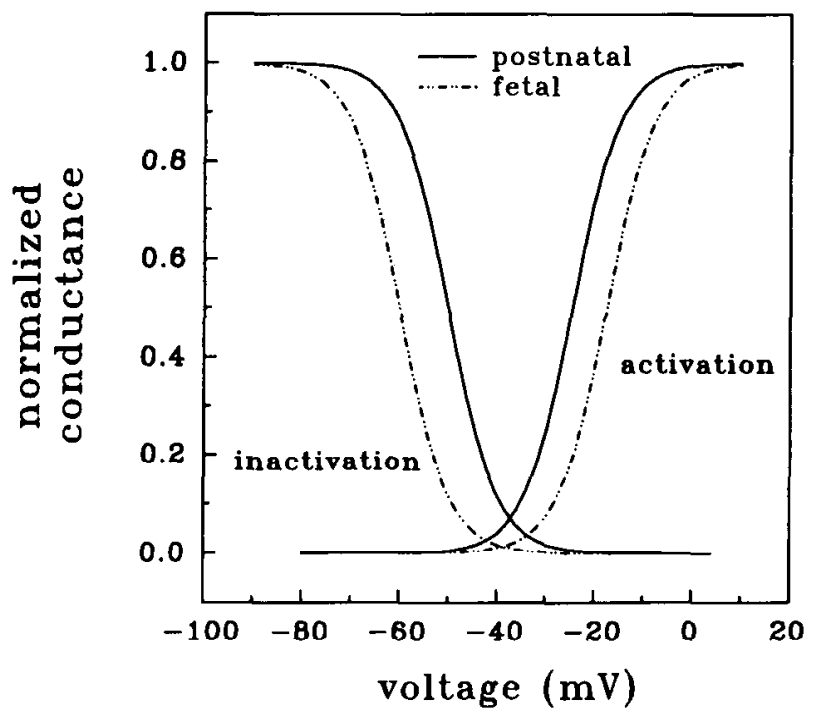

Figure 13. Functional implications of the changes in activation and steady-state inactivation properties in developing RGCs. Activation and steady-state inactivation curves from E30 (broken lines) and postnatal (solid lines) cells are overplotted. With maturation, both curves have shifted so that larger percentages of $\mathrm{Na}$ currents are available for activation in more mature cells, at any given membrane voltage. Furthermore, smaller degrees of depolarization would be required to active the same proportion of $I_{\mathrm{Na}}$.

al., 1983) and prior to any significant innervation of the main retinorecipient nuclei (Williams and Chalupa, 1982; Shatz, 1983). At this age, RGCs were found to be functionally immature. The majority of E30 RGCs were not capable of spiking in response to electrical stimulation, and sodium current densities were correspondingly low. Furthermore, as indicated by the position of $I_{\mathrm{Na}}$ activation and steady-state inactivation curves, larger depolarizations would be required for $\mathrm{Na}$ currents to be activated and, at a resting potential of $-60 \mathrm{mV}$, most of the sodium current would not be available for activation (see Fig. 13).

The following weeks are characterized by developmental changes in spike generation as well as in the properties of $I_{\mathrm{Na}}$. The proportion of spiking neurons increased from $33 \%$ at E30, to $80 \%$ at E45, and $100 \%$ at E55. There was also an increase in the number of RGCs capable of repetitive firing. Such cells first appear around E38 and their percentage gradually increases, reaching almost $72 \%$ in postnatal neurons. At the same time, sodium current densities increase by twofold and both activation and steady-state inactivation curves shift. The functional implications of these shifts are illustrated in Figure 13, in which averaged activation and inactivation curves of young fetal (E30) and postnatal RGCs are overplotted. Note that at aiven mem-

postnatal neuron) and the peaks are aligned at time $=0$. The time constants and the potentials at which these were obtained were as follows, from top to bottom: $3.9,2.1$, and $1.3 \mathrm{msec}$ at $-30,-25$, and -15 $\mathrm{mV}$, respectively, for the $\mathrm{E} 30 \mathrm{RGC} ; 2.6,1.7$, and $0.9 \mathrm{msec}$ at $-40,-35$, and $-25 \mathrm{mV}$, respectively, for the postnatal neuron. $B$, Decay time constants (in milliseconds) are plotted as a function of membrane potential for fetal and postnatal RGCs. Triangles and circles represent postnatal $(n=10)$ and fetal (E30-E35; $n=19)$ cells, respectively. At potentials negative to $-15 \mathrm{mV}$, fetal cells have significantly longer time constants. Average values $\pm \mathrm{SD}$ at $-33 \mathrm{mV}$ are $1.7 \pm 1.0 \mathrm{msec}(n=$ 10) for postnatal and $3.0+1.0 \mathrm{msec}(n=19)$ for fetal cells, whereas at $-25 \mathrm{mV}$ these were $0.9 \pm 0.4$ and $1.9 \pm 0.8 \mathrm{msec}$, respectively. In both cases, the difference in the mean was significant $(p<0.01)$. 
brane potential, the percentage of $\mathrm{Na}$ current available for activation (i.e., percentage of current not inactivated) is markedly larger in older cells, and that smaller depolarizations would be required to activate the same proportion of $I_{\mathrm{Na}}$. Thus, in E30 cells, in order for $25 \%$ of the total (maximum) current to be activated from a membrane potential of $-60 \mathrm{mV}$, a $45 \mathrm{mV}$ depolarization would be required. By contrast, in postnatal neurons similar conditions will activate more than $75 \%$ of the total $I_{\mathrm{Na}}$. If the developmental doubling in current density is also taken into account, there would be a sixfold increase in the amount of the available $\mathrm{Na}$ current between early fetal and postnatal RGCs. In addition, there is a change in the decay time constant of $I_{\mathrm{Na}}$ : at membrane potentials negative to $-15 \mathrm{mV}$, more mature cells are characterized by significantly smaller time constants and the $\tau_{h}$ curve is shifted to more negative values. Slower $I_{\mathrm{Na}}$ decay would tend to retard repolarization of the action potential, and this may relate to the fact that spikes were broader in young fetal neurons.

While each of the developmental changes we observed has been documented in other systems, the particular combination of alterations in the characteristics of $I_{\mathrm{Na}}$ found in fetal cat RGCs has not been reported previously. Ontogenetic increases in $\mathrm{Na}$ current density and a decrease in decay time constants have becn noted in several systems (MacDermott and Westbrook, 1986; Fujii et al., 1988; O'Dowd et al., 1988; McCobb et al., 1990). However, there have also been reports of no significant changes in these parameters (Huguenard et al., 1988; Nerbonne and Gurney, 1989; Park and Ahmed, 1991), and even one case where the change was to the opposite direction (Sontheimer et al., 1991). A developmental change in the voltage dependence of $I_{\mathrm{Na}}$ activation, similar to the one we found in RGCs, has recently been reported in cultured fetal rat diencephalic neurons (Park and Ahmed, 1991). However, in most other studies where this parameter was examined, no significant change was noted (Huguenard et al., 1988; O'Dowd et al., 1988). The voltage dependence of steady-state inactivation has been found to remain constant (Huguenard et al., 1988) or to shift toward either more positive (MacDermott and Westbrook, 1986) or more negative (Sontheimer et al., 1991) values with development. Collectively, these and other studies (for review, see Spitzer, 1991) have revealed a considerable degree of diversity in the maturation of neuronal membrane properties. To some extent, such diversity may reflect the degree to which different developing systems depend on activity to mediate structural refinements of initially exuberant projection patterns.

The factors underlying the combination of developmental changes we observed in $I_{\mathrm{Na}}$ properties of cat RGCs arc presently unknown. All conditions such as dissociation, temperature, and composition of electrode solution were kept the same for experiments at different ages, so the possibility that experimental procedures may account for some of the changes seems unlikely. Adequacy of space clamp was established for all cells included in the present study.

The increase in current density could be due to an increase in the number of channels, the single-channel conductance, and/ or the probability of channels being open. While one could postulate the appearance of a different channel protein with a larger single-channel conductance and modified kinetics, the rather gradual change in activation and steady-state inactivation properties seems to argue against this possibility. It should be noted, however, that due to the spatiotemporal gradient of retinal development, the sample at each age would consist of cells within a broader developmental window. Differential effects of surface charge on the membrane seem unlikely, because the shifts in activation and steady-state inactivation curves are to opposite directions. It is also possible that the differences in gating properties are the result of changes in the lipid environment of the membrane during development, or from association of the channel with other membrane proteins. In this respect, it may be relevant that immunocytochemical studies have revealed that in rat RGCs the $\alpha$-subunit of the Na channel first appears at E15, $4 \mathrm{~d}$ after the first ganglion cells are born, whereas the $\beta$-subunits as well as the high affinity saxitoxin binding are not detected until after birth (Wollner et al., 1988). Thus, it is conceivable that the changes in functional properties of the $\mathrm{Na}$ channel we have documented could relate to the timing in the expression and assembly of the different $\mathrm{Na}$ channel subunits.

Our results revealed sustained and transient spiking patterns in response to electrical stimulation. This finding was unexpected since it is commonly assumed that sustained and transient responses of RGCs to light reflect differences in retinal circuitry (Werblin, 1977). The different response patterns observed in isolated cells could reflect artifacts inherent to the dissociation procedure, for instance, a mechanical disruption of the axon initial segment that is thought to have a high density of $\mathrm{Na}$ channels. However, no correlation was found between spiking patterns and the extent of processes on the cell body, the maximum rate of rise of action potentials, or the cell's specific membrane resistance. Furthermore, Mobbs et al. (1992) have observed sustained and transient responses in isolated salamander RGCs as well as RGC's recorded in retinal slices and found a correlation between responses to light and to injected current. While the role of RGC membrane properties in temporal tuning of the distinct light-mediated responses remains to he established, it seems highly unlikely that procedural factors could account for the protracted and orderly developmental increase in the proportion of RGCs capable of repetitive firing documented in this study.

This increase in excitability as well as the changes in $I_{\mathrm{Na}}$ are largely occurring between E30 and E38, which coincides with the period of massive axon ingrowth and innervation of retinorecipient targets (Williams and Chalupa, 1982; Shatz, 1983; Williams et al., 1986). This raises the intriguing possibility that target contact could be a factor in triggering changes in membrane properties leading to spike generation ability (Conte Camerino et al., 1989). Restructuring of retinal projections in the fetal cat begins around E45, with the formation of ocular domains within the dorsal LGN and the superior colliculus largely completcd by birth (Williams and Chalupa, 1982; Shatz, 1983). Such refinements are thought to be dependent on Na-mediated activity because prenatal infusions of TTX significantly alter the normal restructuring of retinogeniculate terminal arbors (Sretavan et al., 1988). Our results provide direct evidence that cat RGCs can generate sodium-mediated action potentials as early as E38. Furthermore, we have shown that sodium currents in cal RGCs are already essentially mature about 1 week before the beginning of eye-specific segregation. These observations indicate that the functional maturation of $\mathrm{Na}$ currents is not the limiting factor for activity-mediated refinements in the developing visual system.

\section{References}

Barres BA, Silverstein BE, Corey DP, Chun LL (1988) Immunological, morphological, and electrophysiological variation among retinal ganglion cells purified by panning. Neuron 1:791-803. 
Chalupa LM, White CA (1990) Prenatal development of visual system structures. In: Development of sensory systems in mammals (Coleman JR, ed), pp 3-60. New York: Wiley.

Constantine-Paton M, Cline HT, Debski E (1990) Patterned activity, synaptic convergence, and the NMDA receptor in developing visual pathways. Annu Rev Neurosci 13:129-154.

Conte Camerino D, De Luca A, Mambrini M, Vrbova G (1989) Membrane ionic conductances in normal and denervated skeletal muscle of the rat during development. Pfluegers Arch 413:568-570.

Dubin MW, Stark LA, Archer SM (1986) A role for action-potential activity in the development of neuronal connections in the kitten retinogeniculate pathway. J Neurosci 6:1021-1036.

Fujii S, Ayer RJ, DeHaan RL (1988) Development of the fast sodium current in early embryonic chick heart cells. J Membr Biol 101:209223.

Galli L, Maffei L (1988) Spontaneous impulse activity of rat retinal ganglion cells in prenatal life. Science 242:90-91.

Hamill OP, Marty A, Neher E, Sakmann B, Sigworth FJ (1981) Improved patch-clamp techniques for high resolution current recording from cells and cell-free membrane patches. Pfluegers Arch 391:85100.

Horn R, Marty A (1988) Muscarinic activation of ionic currents measured by a new whole-cell recording method. J Gen Physiol 92:145159.

Huguenard JR, Hamill OP, Prince DA (1988) Developmental changes in $\mathrm{Na}^{+}$conductances in rat neocortical neurons: appearance of a slowly inactivating component. J Neurophysiol 59:778-795.

Kalil RE (1990) The influence of action potentials on the development of the central visual pathway in mammals. J Exp Biol 153:261-276.

Kliot M, Shatz CJ (1982) Genesis of different retinal ganglion cell types in the cat. Soc Neurosci Abstr 8:815.

Lipton SA, Tauck DL (1987) Voltage-dependent conductances of solitary ganglion cells dissociated from the rat retina. J Physiol (Lond) 385:361-391.

MacDermott AB, Westbrook GL (1986) Early development of voltage-dependent sodium currents in cultured mouse spinal cord neurons. Dev Biol 113:317-326.

Maffei L, Galli-Resta L (1990) Correlation in the discharges of neighboring rat retinal ganglion cells during prenatal life. Proc Natl Acad Sci USA 87:2861-2864.

McCobb DP, Best PM, Beam KG (1990) The differentiation of excitability in embryonic chick limb motoneurons. J Neurosci 10:2974 2984.

Meister M, Wong ROL, Baylor DA, Shatz CJ (1991) Synchronous bursts of action potentials in ganglion cells of the developing mammalian retina. Science 252:939-943.

Meyer RL (1983) Tetrodotoxin inhibits the formation of refined retinotopography in goldfish. Devel Brain Res 6:293-298.

Mobbs P, Everett K, Cook A (1992) Signal shaping by voltage-gated currents in retinal ganglion cells. Brain Res 574:217-223.

Nerbonne JM, Gurney AM (1989) Development of excitable membrane properties in mammalian sympathetic neurons. J Neurosci 9: 3272-3286.
O'Dowd DK, Ribera AB, Spitzer NC (1988) Development of voltagedependent calcium, sodium, and potassium currents in Xenopus spinal neurons. J Neurosci 8:792-805.

Park CC, Ahmed Z (1991) Characterization of sodium current in developing rat diencephalic neurons in serum-free culture. J Neurophysiol 65:1011-1021.

Shatz CJ (1983) The prenatal development of the cat's retinogeniculate pathway. J Neurosci 3:482-499.

Shatz CJ (1990) Competitive interactions between retinal ganglion cells during prenatal development. J Neurobiol 21:197-211.

Shatz CJ, Kirkwood PA (1984) Prenatal development of functional connections in the cat's retinogeniculate pathway. J Neurosci 4:13781397.

Shatz CJ, Sretavan DW (1986) Interactions between retinal ganglion cells during the development of the mammalian visual system. Annu Rev Neurosci 9:171-207.

Shatz CJ, Stryker MP (1988) Prenatal tetrodotoxin infusion blocks segregation of retinogeniculate afferents. Science 242:87-89.

Skaliora I, Scobey RP, Chalupa LM (1990) Development of excitability in dissociated cat retinal ganglion cells. Soc Neurosci Abstr 16:464.

Skaliora I, Liets LC, Scobey RP, Chalupa LM (1991) Development of membrane currents in dissociated retinal ganglion cells of the cat. Soc Neurosci Abstr 17:186.

Sontheimer H, Ransom BR, Cornell BA, Black JA, Waxman SG (1991) $\mathrm{Na}(+)$-current expression in rat hippocampal astrocytes in vitro: alterations during development. J Neurophysiol 65:3-19.

Spitzer NC (1991) A developmental handshake: neuronal control of ionic currents and their control of neuronal differentiation. J Neurobiol 22:659-673.

Sretavan DW, Shatz CJ, Stryker MP (1988) Modification of retinal ganglion cell axon morphology by prenatal infusion of tetrodotoxin. Nature 336:468-471.

Stryker MP, Harris WA (1986) Binocular impulse blockade prevents the formation of ocular dominance columns in cat visual cortex. $J$ Neurosci 6:2217-2133.

Walsh C, Polley EH, Hickey TL, Guillery RW (1983) Generation of cat retinal ganglion cells in relation to central pathways. Nature 302: 611-614.

Werblin FS (1977) Regenerative amacrine cell depolarization and formation of on-off ganglion cell response. J Physiol (Lond) 264:767785 .

Williams RW, Chalupa LM (1982) Prenatal development of retinocollicular projections in the cat: an anterograde tracer transport study. J Neurosci 2:604-622.

Williams RW, Bastiani MJ, Lia B, Chalupa LM (1986) Growth cones, dying axons, and developmental fluctuations in the fiber population of the cat's optic nerve. J Comp Neurol 246:32-69.

Wollner DA, Scheinman R, Catterall WA (1988) Sodium channel expression and assembly during development of retinal ganglion cells. Neuron 1:727-737. 